\title{
Metallogenic Setting and Evolution of the Pados-Tundra Cr-Bearing Ultramafic Complex, Kola Peninsula: Evidence from Sm-Nd and U-Pb Isotopes
}

\author{
Pavel A. Serov*(D), Tamara B. Bayanova, Ekaterina N. Steshenko, Evgeniy L. Kunakkuzin $\mathbb{D}$ \\ and Elena S. Borisenko \\ Geological Institute of the Kola Science Centre of the Russian Academy of Sciences, 14 Fersman St., \\ Apatity 184209, Russia; tamara@geoksc.apatity.ru (T.B.B.); steshenko@geoksc.apatity.ru (E.N.S.); \\ kunakkuzin@geoksc.apatity.ru (E.L.K.); borisenko@geoksc.apatity.ru (E.S.B.) \\ * Correspondence: serov@geoksc.apatity.ru; Tel.: +79-5330-197-08
}

Received: 23 January 2020; Accepted: 17 February 2020; Published: 19 February 2020

\begin{abstract}
The article presents new $\mathrm{Sm}-\mathrm{Nd}$ and $\mathrm{U}-\mathrm{Pb}$ geochronological data on rocks of the poorly studied Pados-Tundra Cr-bearing complex. It is part of the Notozero mafic-ultramafic complex (western Kola Peninsula) and occurs at the border of the Paleoproterozoic Lapland Granulite Belt and the Archean Belomorian composite terrain. The Pados-Tundra complex hosts two major zones, the Dunite and Orthopyroxenite Blocks. Dunites are associated with four levels of chromite mineralization. Isotope Sm-Nd studies of dunites, harzburgites, and orthopyroxenites from the central part of the complex have been carried out. The isochron Sm-Nd age on 11 whole-rock samples from a rhythmically layered series of the complex is $2485 \pm 38 \mathrm{Ma}$; the mineral Sm-Nd isochron for harzburgites shows the age of $2475 \pm 38 \mathrm{Ma}$. It corresponds with the time of large-scale rifting that originated in the Fennoscandian Shield. When the rhythmically layered series of the intrusion and its chromite mineralization were formed, hornblendite dykes intruded. The U-Pb and $\mathrm{Sm}-\mathrm{Nd}$ research has estimated their age at ca. $2080 \mathrm{Ma}$, which is likely to correspond with the occurrence of the Lapland-Kola Ocean. According to isotope Sm-Nd dating on metamorphic minerals (rutile, amphibole), the age of postmetamorphic cooling of rocks in the complex to $650-600{ }^{\circ} \mathrm{C}$ is $1872 \pm 76$ $\mathrm{Ma}$. The $\mathrm{U}-\mathrm{Pb}$ age on rutile from a hornblendite dyke $(1804 \pm 10 \mathrm{Ma})$ indicates further cooling to $450-400{ }^{\circ} \mathrm{C}$. The conducted research has determined the early Proterozoic age of rocks in the rhythmically layered series in the Pados-Tundra complex. It is close to the age of the Paleoproterozoic ore magmatic system in the Fennoscandian Shield that developed 2.53-2.40 Ga ago. Later episodes of alterations in rocks are directly related to main metamorphic episodes in the region at the turn of 1.9 Ga. Results of the current study expand the geography of the vast Paleoproterozoic East Scandinavian Large Igneous Province and can be applied for further studies of similar mafic-ultramafic complexes.
\end{abstract}

Keywords: Fennoscandian Shield; Arctic region; Sm-Nd; U-Pb; mafic-ultramafic complexes; metallogeny; layered intrusions; ore magmatic system; geochronology; isotope methods

\section{Introduction}

In the northeastern Baltic Shield, large-scale mafic-ultramafic deposits of $\mathrm{Cu}-\mathrm{Ni}$-Co, platinum group elements (PGE), and Fe-Ti-V are economically significant, in particular, concerning critical raw materials, such as PGE (platinum group metals) and V. These are major Cu-Ni-Co-Cr + PGE deposits in the Monchegorsk ore area [1-5] and Pechenga [6-8], Fe-Ti-V Kolvitsa deposit [9,10], PGE and Cu-Ni Fedorovo-Pana layered complex [11-14] and Burakovsky intrusion [15], Cu-Ni-Co + PGE deposits in Finland: Kemi [5,16], Penikat [17,18], Akanvaara, Koitelainen [19], Tornio [20], and so forth. 
The dated deposits were formed in two major episodes, at 2.53-2.39 Ga and 2.0-1.8 Ga, corresponding to the early $[5,15,16,21-41]$ and late $[8,42]$ stages of rifting in the Fennoscandian Shield. However, not all of the deposits are dated. In this respect, the Pados-Tundra complex is one of the least investigated. Its study is both scientifically and economically important, considering the acceleration of the raw material potential of the Russian Arctic.

According to earlier geological-geophysical research, the complex formed at the turn of 2.5-2.4 Ga and has a structure, composition, and mode of occurrence similar to Paleoproterozoic layered complexes [43-45]. However, primary geochronological research in 2008 provided a younger age of $2.15 \mathrm{Ga}[46,47]$. The dating was based on $\mathrm{Sm}-\mathrm{Nd}$ isochron measurements with rock-forming and metamorphogenic minerals (amphibole, rutile). Results of the previous Sm-Nd dating should be reviewed and supplementary isotope studies are required. In particular, plots in ${ }^{143} \mathrm{Nd} /{ }^{144} \mathrm{Nd}$ vs $1 /[\mathrm{Nd}]$ coordinates show a linear relationship for the obtained results, which may indicate getting a false isochron of mixing. This work aims to (i) date the Pados-Tundra ultramafic intrusion, (ii) detect its position in the general metallogenic scale of Fennoscandia, and (iii) justify the main time constraints of rock processing in the complex under the impact of tectono-thermic episodes (metamorphism and collision at $1.9 \mathrm{Ga}[42])$.

\section{Geological Settings}

\subsection{Regional Geology}

The Fennoscandian Shield has the Archean basement that formed at ca. 3.5-3.2 Ga and consists of the Kola, Karelian, and Norrbotten cratonic cores, each with an associated cover of Paleoproterozoic sedimentary and volcanic rocks [48]. Together with the younger Svecofennian orogenic zone, Fennoscandia represents the largest crustal segment, spanning across the northern part of the East European Craton (Baltica). The Kola and Karelian cratons are considered fragments of either the late Archean supercontinent, sometimes referred to as Kenorland [49-51], or a yet unconstrained supercraton [52], which in either case, broke apart at 2.5-2.0 Ga, prior to the amalgamation of the next supercontinent, Columbia (Nuna), at ca. 1.9-1.7 Ga [53]. In the Paleoproterozoic (2.50-1.95 Ga), the Karelian craton experienced a number of intraplate magmatic events [54], some of which were likely parts of large igneous provinces (LIPs) [40]. Paleoproterozoic volcanic and sedimentary volcanic successions were deposited and are now preserved in the Onega structure, Perapohja schist belt, Salla-Kuolajarvi basin, and so forth. Terrigenous sequences containing black shales accumulated in the Onega and Salla-Kuolajarvi Basins between 2.06 and $1.95 \mathrm{Ga}$ [54].

The Pados-Tundra complex occurs in the western part of the Kola Peninsula as a fragment of the Notozero ultramafic complex (Figures 1 and 2) [43-45]. The Notozero complex stretches $40 \mathrm{~km}$ transversally as a chain of the Khanlaut-Varaka, Pados-Tundra, Chapes-Varaka, Lotmvaara, and other intrusions. According to regional studies, this zone is the southeastern continuation of the Tanaelv Greenstone Belt [55]. It occurs at the border of the Lapland Granulite Belt (LGB) and the Archean Belomorian Belt, which is the northern part of the Karelian Craton (Figure 2). The LGB is located between the Karelian Craton in the south and the Inari Craton in the north. The Tanaelv Belt $[55,56]$ separates the LGB from the Belomorian complex. A number of geological and petrological studies [56-59] consider the Tanaelv Belt as a strongly deformed sequence underlying the LGB and tectonically overlying less deformed rocks of the Belomorian Complex in the Karelian Craton [60]. Abundant isotope data on rocks from the eastern Tanaelv suggest that it formed over 2.5-1.85 Ga [26,61]. Isotope data indicate that granulites in the LGB have the similar age of $1.9 \mathrm{Ga}$ [62-64]. The rocks of the Belomorian Complex are significantly older (2.86-2.58 Ga) [65,66]. 


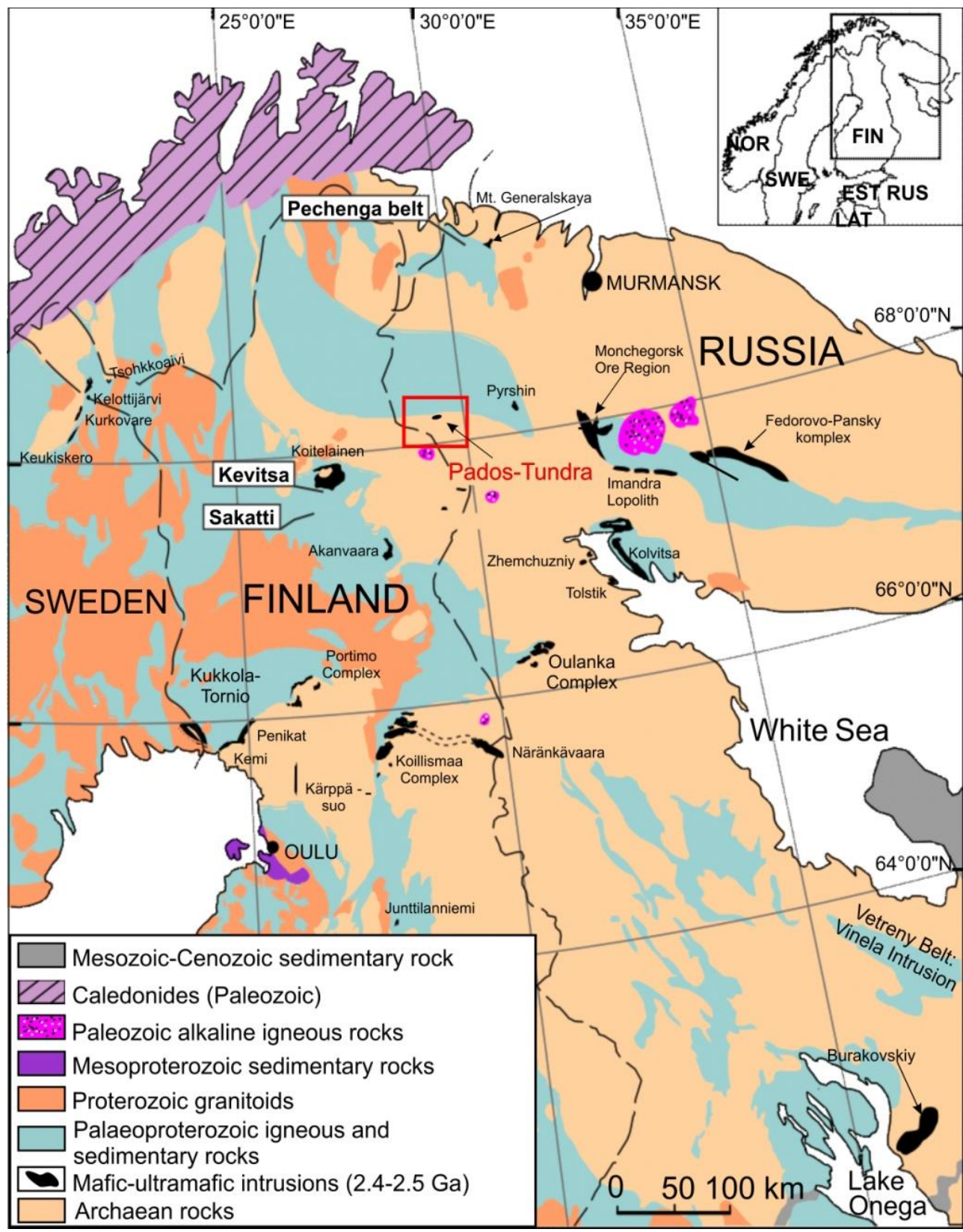

Figure 1. Map of mafic-ultramafic layered intrusions (2.53-2.39 Ga) in the Fennoscandian Shield, modified after [5,41]. 


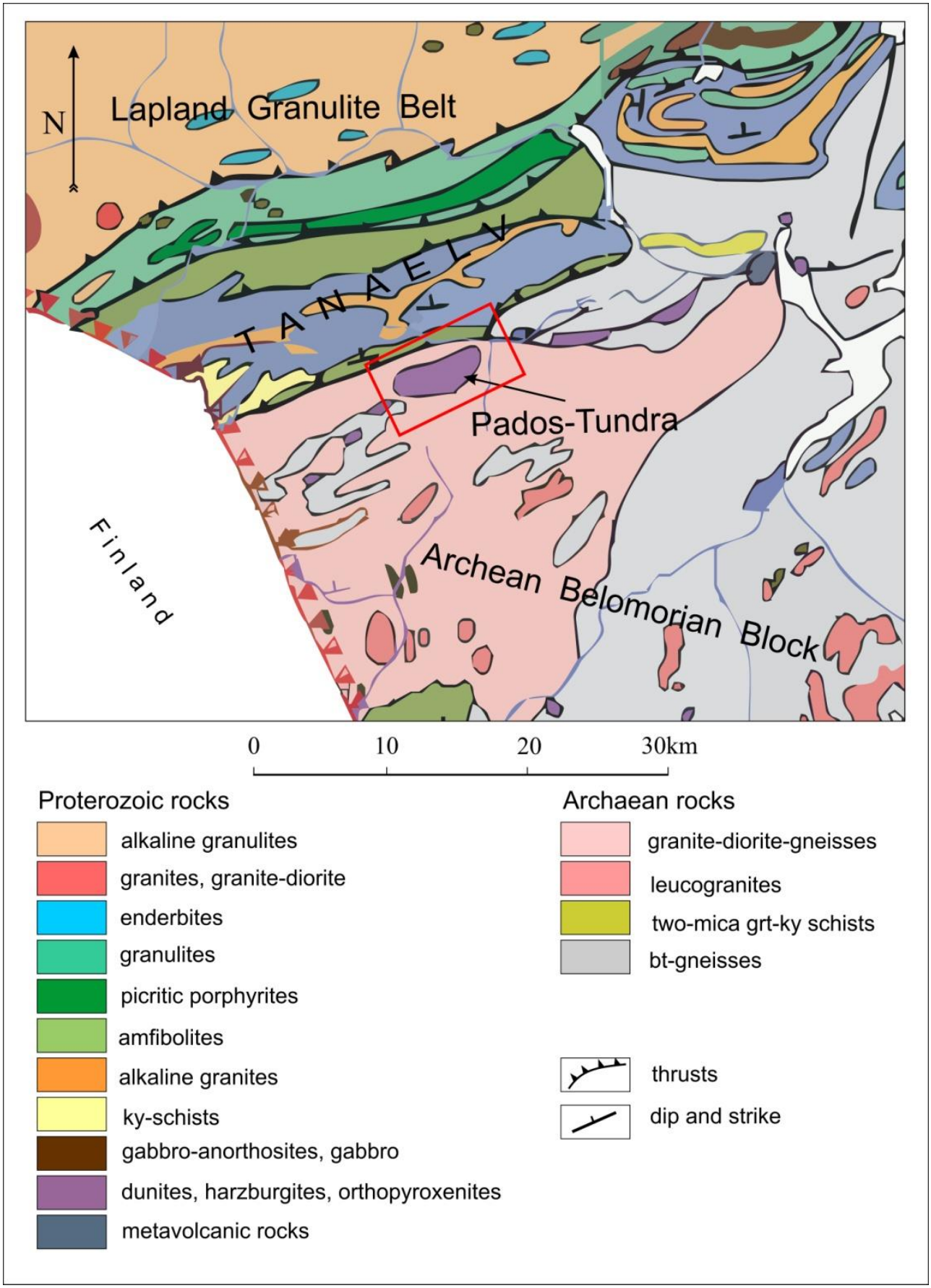

Figure 2. Geological map of the Pados-Tundra area.

\subsection{The Pados-Tundra Complex}

Geotectonic settings of the Notozero complex and its occurrence at the boundary of the folded belt and the Archean geoblock can be correlated with settings of some chromite-bearing stratiform massifs (Campo Formose [67], Kemi [68,69], etc.). Massifs of the Notozero complex, Mt. Lyavaraka [70] and Falaley on the Kola Peninsula and in the North Karelian ultramafic belt, have been defined as early Proterozoic dunite-harzburgite formations [71].

The Pados-Tundra complex (Figures 2 and 3) takes the central position in the complex, being the largest in scale and best studied. In the 1990s, JSC "Murmansk Geological Prospecting Expedition" carried out a geological survey of the Pados-Tundra complex [43], searching for mineral resources. 
Geophysical, mining, and drill works (200 m deep boreholes) were carried out. No profound survey has been provided ever since.

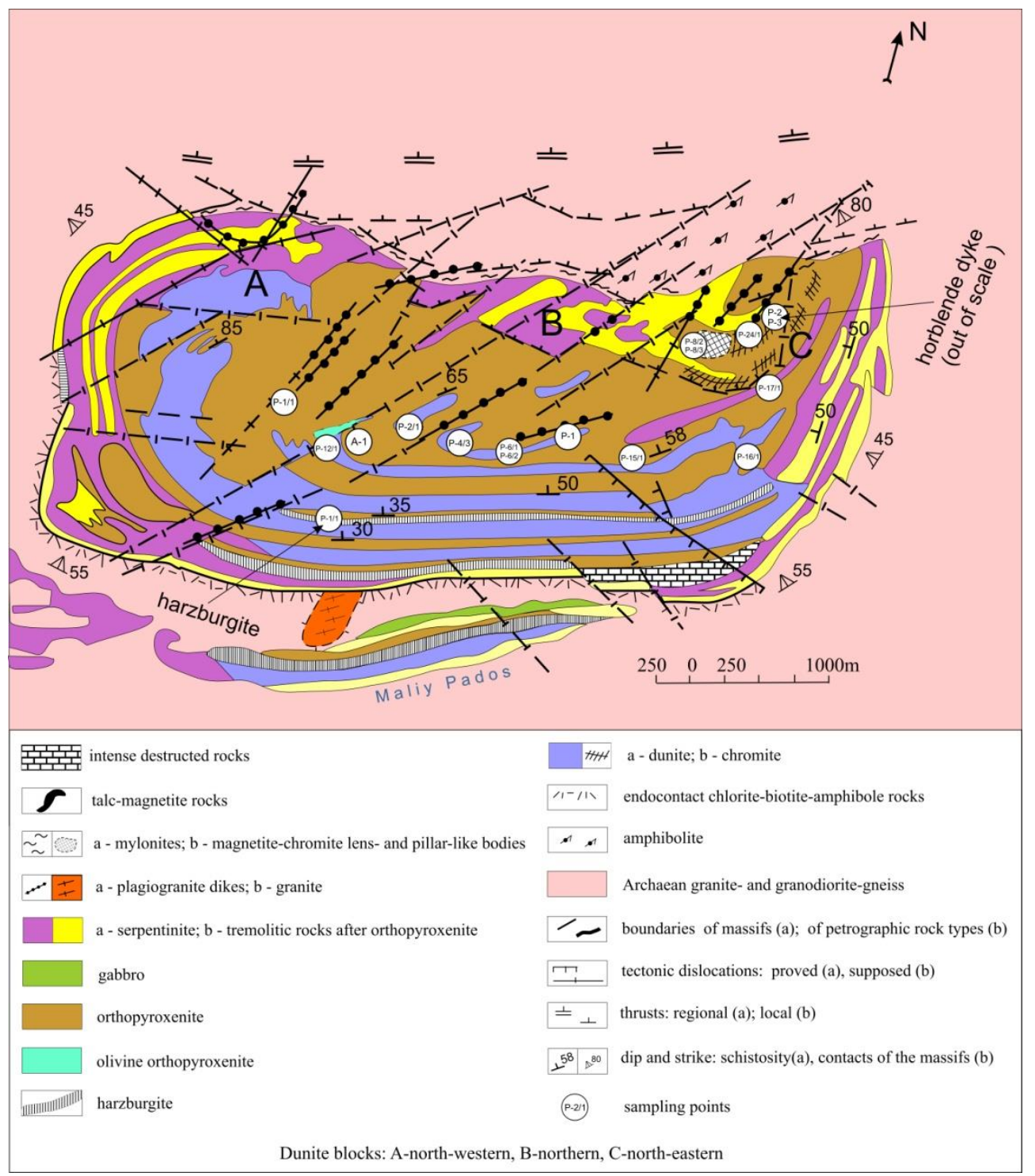

Figure 3. Geological map of the Pados-Tundra and Maliy Pados complexes (kindly provided by V.F. Smolkin, unpublished data; amended).

At the present-day erosion level, the intrusion is represented by a body extending some $13 \mathrm{~km}^{2}$ to the northeast (Figure 3). Host rocks are composed of Archean granite and granite-diorite gneisses with the northeastern strike and the northwestern dip at the angles of 20-45. The southern and western contacts of the complex have an intrusion pattern, the northern contact has the tectonic pattern, the eastern contact is not studied. In its exocontact, biotite-chlorite-amphibole schists and mylonites (1-5 $\mathrm{m}$ thick) are developed over granite and granodiorite gneisses. The complex was subject to the Karelian tectonogenesis, which is associated with the obduction of the LGB over the Belomorian Geoblock, processes of folding and fracturing, and acid magmatism. As a result, the initial form and geological structure of the complex experienced significant alterations [43], that is, turn-up of the flanks, superposed tectonometamorphism, replacement of rocks, and substitution of gentle for steep dip and strike patterns of rock layers.

The complex contains three major structural units: an endocontact zone, a rhythmically layered series, and an upper zone (Figures 3 and 4). The 10-20 m thick endocontact zone is composed of 
amphibolite resulting from the metamorphism of mafic rocks. The rhythmically layered series hosts a number of rocks from dunites to orthopyroxenites and constitutes most of the complex. In total, there are seven rhythms, each of them starting with dunites and ending with orthopyroxenites [43,47]. Each rhythm starts with dunites and is associated levels of syngenetic chromite mineralization (Figure 4). Rocks of this series contain dykes of meso- and leucocratic gabbro, diorites, and hornblendites (up to $1.5 \mathrm{~m}$ thick) that are bedded conformably with their host rocks. However, these dykes are not present in every rhythm, therefore, their syngentic nature is doubted. Gabbro and diorites occur in boreholes in the northwestern part of the complex only. The upper gabbronoritic zone is partly traced in the northeast of the complex; its estimated thickness is $\sim 400 \mathrm{~m}$. The main volume of this zone seems to be overlapped by host rocks as a result of obduction. Intensely amphibolized gabbroic rocks were found in this upper zone during field works. These rocks seem to be relics of gabbronorites at the end of the Pados-Tundra complex section.

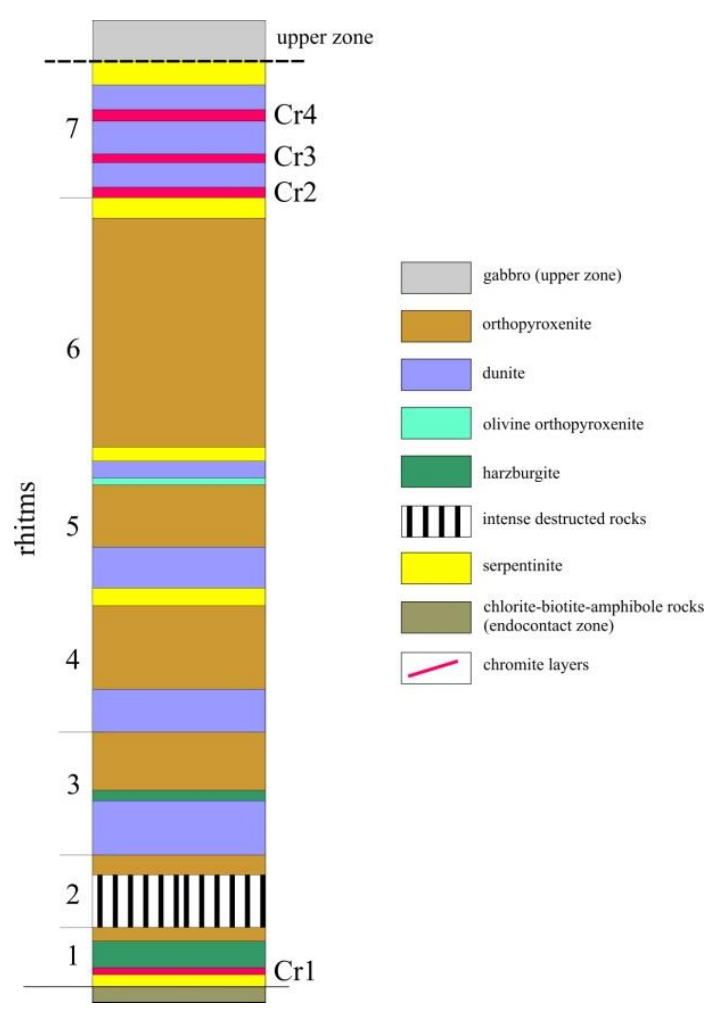

Figure 4. A generalized column, after [43,72].

The complex is marked by granite dykes $[40,43]$. They intersect the whole complex from the northeast to the southwest. Intrusion of these granites is linked to the development of tectonic faults of the northwestern strike in the complex. The genesis of these granites is associated with the acid volcanism activity at the turn of $1.9 \mathrm{Ga}$; however, these granites are not dated [43].

Chromitites occur in the seventh rhythm only as irregular lenses and stock-like bodies.

The gabbronorite zone is partly observed within the Maliy Pados (Figure 3). The setting of the satellite Maliy Pados complex is a disputable issue. Some researchers suggest that it formed at the same time as the main Pados-Tundra body [43]. Others believe that it disintegrated later from a minor block of the Pados-Tundra [72-74].

\subsection{Chromite Ore Bodies}

The complex is characterized by a high content of $\mathrm{Cr}$ (up to $1.10 \%$ ), which is concentrated mainly in chrome spinellids. The complex hosts four horizons of bedded disseminated chromite ores and a series of lens-like and columnar bodies of chromite ores [43,72-74]. All of the found chromite occurrences are 
associated with dunites or serpentinites after dunites (Figure 4). The first chromite horizon Cr1 with the thickness of $0.04-0.5 \mathrm{~m}$ is traced in fragments at the bottom of serpentinites after dunites of the first rhythm. The second, third, and fourth horizons, as well as lenses and columnar bodies, are traced within the northeastern dunite block of the seventh rhythm (Figures 3 and 4).

The second horizon, $\mathrm{Cr}$, occurs at the footwall of the studied block. At the surface, the contact of this horizon with underlying orthopyroxenites is low and complicated by folded and block forms. Outcrops of this horizon are assumed to be $1400 \mathrm{~m}$ long; there are numerous bodies with the length of 0.1-0.6 m, densely disseminated and with massive chromite mineralization.

The third horizon, Cr3, occurs in the central part of this block and is traced for $320 \mathrm{~m}$ by stripping. The horizon hosts 1-5 $\mathrm{m}$ long and $0.13-0.45 \mathrm{~m}$ thick lens bodies jointed by chromite veinlets for $140 \mathrm{~m}$ in the northeastern part of the block. Further south for $180 \mathrm{~m}$, the horizon is divided into separate blocks displaced from 1-2 to $15 \mathrm{~m}$. The chromite horizon has clear contacts with host dunites.

The fourth horizon, $\mathrm{Cr} 4$, occurs in the hanging wall of the dunite block and strikes for $85 \mathrm{~m}$. This horizon also has a heterogeneous structure with $0.2-1.75 \mathrm{~m}$ thick swells jointed by mineralized veinlets. The contacts of the horizon with host dunites are sharp [43,72,74].

It is assumed that horizons $\mathrm{Cr} 2-\mathrm{Cr} 4$ within the dunite block were altered at the turn of $1.9 \mathrm{Ga}$ as a result of tectono-thermic episodes associated with the obduction of Lapland granulites. As a result, chromite layers broke up, and lenses and columnar bodies occurred. Notably, there are still no geochronological data on these episodes.

According to the density of the chrome-spinellid dissemination, poor and relatively rich ores are identified in the chromite mineralization of the bedded morphological type ( $\mathrm{Cr} 2, \mathrm{Cr} 3, \mathrm{Cr} 4)$. Poor ores with the spinellid content of 30-40\% have an irregularly grained and disseminated texture with certain densely disseminated areas. Their structure is sideronitic and xenomorphic-granular. Rich ores contain $60-85 \%$ of chrome spinellids; they have a massive densely disseminated texture and a hypidiomorphic-granular and idiomorphic-granular structure. The rich ore hosts minor amounts of sulfides represented by fine pentlandite and chalcopyrite phenocrysts.

Discrete steeply dipping lenses and columnar magnetite-chromite bodies are exposed in the western part of the dunite block in the continuation of the third and fourth horizons of disseminated chromite ores. In total, there are 120 such exposed bodies, the area of their cross-section ranges from $33 \mathrm{~cm}^{2}$ to $1.4 \mathrm{~m}^{2}$, and the bodies are traced to the depth of $1 \mathrm{~m}$ in sections. Magnetite-chromite bodies are represented by massive densely disseminated and drained ores. It is irregularly grained; larger $(0.2-0.8 \mathrm{~mm})$ isometric and rounded crystals of chrome spinellids are surrounded by clustered crystals of chrome magnetites. Magnetite-chromite bodies occur among serpentinized and schistose dunites saturated in fine veinlets of talcite, magnesite, magnetite, and quartz.

Both rich and poor chromites in disseminated ore beds have a heterogeneous composition manifested in their zoned structure. In reflected light, central parts of chrome spinellid grains differ from marginal areas that produce fine rims with a worse reflecting capacity. In transmitted light, most of them are brownish red in contrast to black marginal areas [43].

\section{Samples and Analytical Methods}

\subsection{Samples}

Large (up to $20 \mathrm{~kg}$ ) samples of dunites, harzburgites, and orthopyroxenites and one sample from a hornblendite dyke were selected from a rhythmically layered series of the complex (dunite block, fifth and sixth rhythms mainly). A harzburgite sample (P-1/1) was separately selected from the third rhythm for further extraction of mineral fractions. Sampling points were selected based on several factors, mainly on the clear geological occurrence of a sample regarding the structure of the complex, the absence of visible alterations of the rock as a result of superposed processes, sampling representativeness of the location, easy access to the site, and safe sampling. Gabbronorite was sampled 
in the upper zone of the Maliy Pados complex for the U-Pb studies. Sampling points are shown in Figure 3.

\subsection{Description of Geochronological Samples}

Harzburgite (P-1/1) had a panidiomorphic-grained structure. It consisted of idiomorphic prismatic and polygonal grains of orthopyroxene (rarely xenomorphic) and olivine (70\%). There were single grains of clinopyroxene and ore minerals (magnetite, chromite).

Orthopyroxenite (A-1) had a hypidiomorphic-grained structure. It comprised orthopyroxene (90-95\%) and plagioclase (2-4\%). The latter occurred as irregular segregations; orthopyroxene was idiomorphic, but there were amphibolized areas. Ore minerals were represented by chromite and magnetite. The rock had a massive texture.

Two generations of $\mathrm{Zr}$ (Figure 5) and one rutile variety were extracted from a hornblendite sample for $\mathrm{U}-\mathrm{Pb}$ research.

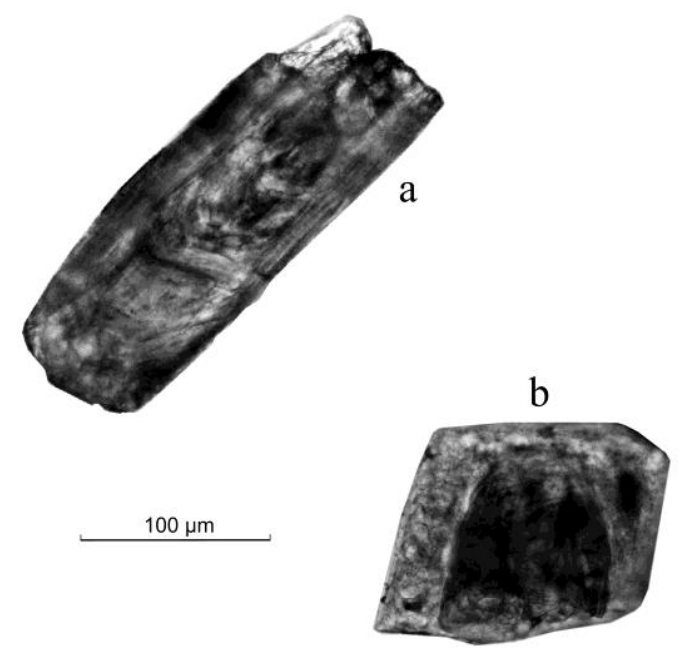

Figure 5. Zircons from a hornblendite sample of the Maliy Pados (sample P-3). (a) the first generation of $\mathrm{Zr}$; (b) the second generation of $\mathrm{Zr}$.

The first generation of $\mathrm{Zr}$ was represented by elongated-prismatic light brown crystals and their debris. The crystals were transparent with a glassy luster and their surface was corroded. The average size was $0.21 \times 0.105 \mathrm{~mm}$; the elongation coefficient $\left(\mathrm{C}_{\mathrm{el}}\right)$ was 2 . The weight value of an average crystal was $9.3 \times 10^{-6} \mathrm{~g}$. A distinct zonation and transverse cracks were observed in immersion. Blurred and dark areas occurred along zonal boundaries and cracks. The second Zr variety was represented by grayish yellow debris. The grains were transparent with a glassy luster and their surface was corroded. The average size was $0.175 \times 0.14 \mathrm{~mm} ; \mathrm{C}_{\mathrm{el}}$ was 1.3 . A distinct zonation and various cracks rimmed by dark areas were observed in immersion. Rutile was represented by a dark red variety. The grains were nontransparent with a glassy luster and their surface was corroded. The average size was $0.175 \times 0.14 \mathrm{~mm} ; \mathrm{C}_{\mathrm{el}}$ was 1.3 .

\subsection{Sm-Nd Method}

The isotope research was carried out in the Collective Use Center of the Kola Science Center RAS (Apatity, Russia). First, the samples were prepared by crushing, then minerals were separated using heavy liquids and mineral fractions were selected under binocular microscope.

In order to define concentrations of $\mathrm{Sm}$ and $\mathrm{Nd}$, the sample was mixed with a compound tracer ${ }^{149} \mathrm{Sm} /{ }^{150} \mathrm{Nd}$ prior to dissolution. It was then diluted with a mixture of $\mathrm{HF}+\mathrm{HNO}_{3}$ (or $+\mathrm{HClO}_{4}$ ) in Teflon sample bottles at a temperature of $100{ }^{\circ} \mathrm{C}$ until complete dissolution. Further extraction of $\mathrm{Sm}$ and $\mathrm{Nd}$ was carried out using standard procedures with two-stage ion-exchange and extraction-chromatographic separation using ion-exchange tar "Dowex" $50 \times 8$ in 
chromatographic columns employing $2.3 \mathrm{~N}$ and $4.5 \mathrm{~N} \mathrm{HCl}$ as an eluent. The separated Sm and Nd fractions were transferred into a nitrate form, whereupon the samples (preparations) were ready for mass-spectrometric analysis.

The isotope $\mathrm{Nd}$ composition and $\mathrm{Sm}$ and $\mathrm{Nd}$ contents were measured with a 7-channel solid-phase mass-spectrometer Finnigan-MAT 262 (RPQ) in a static double-band mode, using Ta + Re filaments. A mean value of ${ }^{143} \mathrm{Nd} /{ }^{144} \mathrm{Nd}$ ratio in a $\mathrm{JNd}_{\mathrm{i}}-1$ standard was $0.512081 \pm 13(\mathrm{~N}=11)$ in the test period. An error in ${ }^{147} \mathrm{Sm} /{ }^{144} \mathrm{Nd}$ in ratios was $0.3 \%(2 \sigma)$, which is a mean value for 7 measurements in a BCR-2 standard [75]. An error in estimation of isotope $\mathrm{Nd}$ composition in an individual analysis was up to $0.01 \%$ for minerals with low Sm and Nd contents. The blank intralaboratory contamination was $0.3 \mathrm{ng}$ in $\mathrm{Nd}$ and $0.06 \mathrm{ng}$ in $\mathrm{Sm}$. The accuracy of estimation of Sm and $\mathrm{Nd}$ contents was $\pm 0.5 \%$. Isotope ratios were normalized per ${ }^{146} \mathrm{Nd} /{ }^{144} \mathrm{Nd}=0.7219$, and then recalculated for ${ }^{143} \mathrm{Nd} /{ }^{144} \mathrm{Nd}$ in $\mathrm{J}_{\mathrm{Ndi}}-1=0.512115$ [76]. Parameters of isochrons were estimated using ISOPLOT program complex (ISOPLOT Version 3.6. Berkeley Geochronology Center, Berkeley, USA) [77]. Values of $\varepsilon N d(T)$ and $\mathrm{T}_{(\mathrm{DM})}$ model ages were estimated using present-day values of CHUR (Chondritic Uniform Reservoir) after [78] at $\left({ }^{143} \mathrm{Nd} /{ }^{144} \mathrm{Nd}=0.512630,{ }^{147} \mathrm{Sm} /{ }^{144} \mathrm{Nd}=0.1960\right)$ and $\mathrm{DM}$ after $[79]\left({ }^{143} \mathrm{Nd} /{ }^{144} \mathrm{Nd}=0.513151\right.$, $\left.{ }^{147} \mathrm{Sm} /{ }^{144} \mathrm{Nd}=0.2136\right)$.

\subsection{U-Pb Method}

The method proposed by Krogh [80] was used to dissolve samples in strong (48\%) hydrofluoric acid at the temperature of $205-210^{\circ} \mathrm{C}$ over 1-10 days. In order to dissolve fluorides, the samples were reacted with $3.1 \mathrm{~N} \mathrm{HCl}$ at the temperature of $130{ }^{\circ} \mathrm{C}$ for 8-10 $\mathrm{h}$. To determine the isotope composition of $\mathrm{Pb}$ and concentrations of $\mathrm{Pb}$ and $\mathrm{U}$, a sample was divided into two aliquots in $3.1 \mathrm{~N} \mathrm{HCl}$, then a mixed ${ }^{208} \mathrm{~Pb} /{ }^{235} \mathrm{U}$ tracer was added. $\mathrm{Pb}$ and $\mathrm{U}$ were separated on an AG $1 \times 8,200-400$ mesh anion exchanger in Teflon columns. A laboratory blank for the whole analysis was $<0.1-0.08 \mathrm{ng}$ for $\mathrm{Pb}$ and 0.01-0.04 ng for U. All isotope determinations were made on Finnigan MAT-262 mass spectrometers (Geological Institute KSC RAS, Apatity, Russia). The Pb isotope composition was analyzed on a secondary-ion multiplier on a Finnigan MAT-262 in an ion-counting mode. Measurements of the $\mathrm{Pb}$ isotope composition are accurate to $0.025 \%$ when calibrated against NBS SRM-981 and SRM-982 standards. $\mathrm{U}$ and $\mathrm{Pb}$ concentrations were measured in a single filament mode with $\mathrm{H}_{3} \mathrm{PO}_{4}$ and silica gel added. The method described in $[81,82]$ was used. $\mathrm{Pb}$ and $\mathrm{U}$ concentrations were measured in temperature ranges of $1350-1450^{\circ} \mathrm{C}$ and $1450-1550{ }^{\circ} \mathrm{C}$, respectively. Isotope ratios were corrected for mass discrimination during static processing of replicate analyses of the SRM-981 and SRM-982 standards $(0.12 \pm 0.04 \%$ per a.m.u. for the Finnigan MAT-262). Errors in the U-Pb ratios were calculated during the statistical treatment of replicate analyses of the IGFM- 87 standard. They were assumed equal to $0.5 \%$ for Finnigan MAT-262. Isochrons and sample points were calculated using the PBDAT (version 1.22, United States Geological Survey, Reston, VA, USA) and Isoplot programs (Version 2.05, Berkeley Geochronology Center, Berkeley, CA, USA) [83,84]. Age values were calculated with the conventional decay constants for U [85]. All errors were reported for a 2-sigma level. Corrections for common $\mathrm{Pb}$ were made according to [86]. Corrections were also made for the composition of $\mathrm{Pb}$ separated from syngenetic plagioclase or microcline, if the admixture of common $\mathrm{Pb}$ was $>10 \%$ of the overall $\mathrm{Pb}$ concentration and the ${ }^{206} \mathrm{~Pb} /{ }^{204} \mathrm{~Pb}$ ratios were $<1000$.

\section{Results}

\subsection{Dating of the Complex}

An Sm-Nd isochron was constructed based on 11 whole-rock samples. It complies with the age of $2485 \pm 77 \mathrm{Ma}, \varepsilon \mathrm{Nd}(\mathrm{T})=+2.0 \pm 0.7$ (Figure 6, Table 1). The model Sm-Nd age $\left(\mathrm{T}_{\mathrm{DM}}\right)$ of the analyzed samples is close to $2.7-2.8 \mathrm{Ga}$. The mineral $\mathrm{Sm}-\mathrm{Nd}$ isochron on pyroxenes, chrome spinellid, and rock (orthopyroxenite, sample A-1, data from [47]) conforms to the age of ca. 1.87 Ga (Figure 6, Table 1). The estimated age is close to the time of the metamorphic event at the turn of $1.9 \mathrm{Ga}$ [62]. 


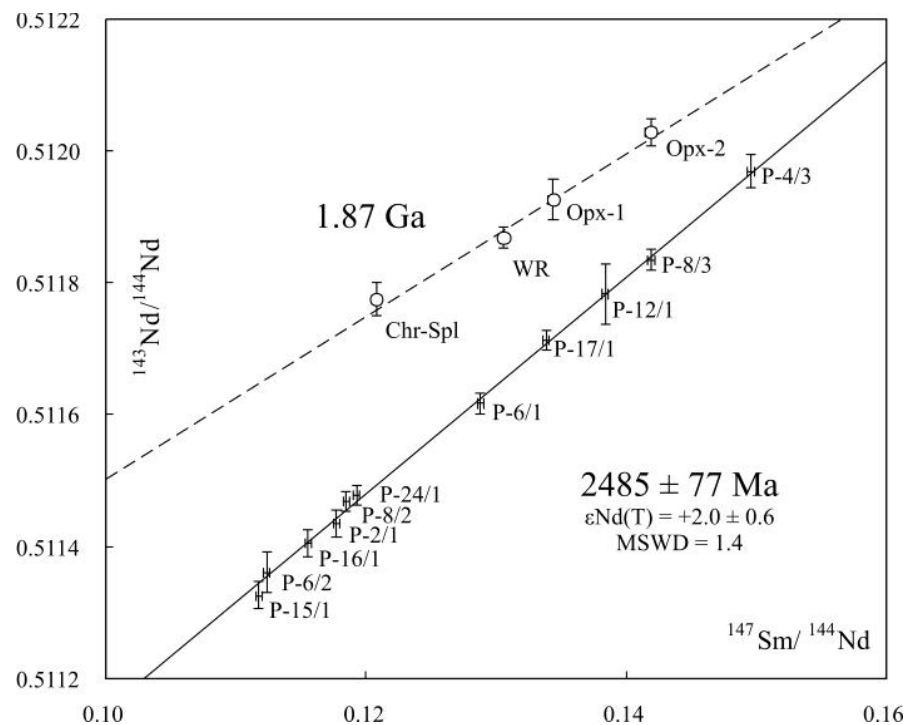

Figure 6. Sm-Nd isochrones for rocks and minerals of rhythmically layered series in the complex.

Table 1. Results of isotope Sm-Nd studies of rocks and minerals of the Pados-Tundra complex.

\begin{tabular}{|c|c|c|c|c|c|c|c|c|}
\hline \multirow[t]{2}{*}{ Sample } & \multirow[t]{2}{*}{ Rock Type } & \multirow[t]{2}{*}{ Rhythm } & \multicolumn{2}{|c|}{$\begin{array}{c}\text { Concentration, } \\
\text { ppm }\end{array}$} & \multicolumn{2}{|c|}{ Isotope Ratios } & \multirow{2}{*}{$\begin{array}{l}\mathrm{T}_{\mathrm{DM}} \\
\mathrm{Ma}\end{array}$} & \multirow{2}{*}{$\varepsilon_{N d}(T)$} \\
\hline & & & $\mathrm{Sm}$ & $\mathrm{Nd}$ & ${ }^{147} \mathrm{Sm} /{ }^{144} \mathrm{Nd}$ & ${ }^{143} \mathrm{Nd} /{ }^{144} \mathrm{Nd}$ & & \\
\hline P-15/1 & $\begin{array}{l}\text { Serpentinized } \\
\text { harzburgite }\end{array}$ & 5 & 0.068 & 0.346 & 0.1185 & $0.511469 \pm 14$ & 2681 & +2.3 \\
\hline P-16/1 & $\begin{array}{l}\text { Serpentinized } \\
\text { olivinite }\end{array}$ & 5 & 0.013 & 0.064 & 0.1177 & $0.511436 \pm 20$ & 2712 & +1.9 \\
\hline $\mathrm{P}-2 / 1$ & $\begin{array}{l}\text { Olivine pyroxenite } \\
\text { (harzburgite) }\end{array}$ & 5 & 0.028 & 0.125 & 0.1338 & $0.511713 \pm 11$ & 2734 & +2.1 \\
\hline P-4/3 & Pyroxenite & 6 & 0.037 & 0.157 & 0.1420 & $0.511835 \pm 16$ & 2784 & +1.9 \\
\hline $\mathrm{P}-6 / 1$ & Harzburgite & 5 & 0.024 & 0.106 & 0.1384 & $0.511783 \pm 43$ & 2757 & +2.0 \\
\hline P-6/2 & Olivinite & 5 & 0.010 & 0.055 & 0.1155 & $0.511405 \pm 22$ & 2698 & +2.0 \\
\hline $\mathrm{P}-12 / 1$ & Pyroxenite & 6 & 0.017 & 0.091 & 0.1118 & $0.511326 \pm 20$ & 2717 & +1.6 \\
\hline P-8/3 & $\begin{array}{l}\text { Serpentinite } \\
\text { (after dunite) }\end{array}$ & 7 & 0.028 & 0.130 & 0.1288 & $0.511617 \pm 15$ & 2742 & +1.9 \\
\hline P-8/2 & Chromitite & 7 & 0.015 & 0.075 & 0.1193 & $0.511478 \pm 15$ & 2689 & +2.2 \\
\hline P-17/1 & $\begin{array}{l}\text { Serpentinized } \\
\text { orthopyroxenite }\end{array}$ & 7 & 0.037 & 0.149 & 0.1496 & $0.511969 \pm 42$ & 2799 & +2.0 \\
\hline $\mathrm{P}-24 / 1$ & Olivinite & 7 & 0.021 & 0.115 & 0.1124 & $0.511361 \pm 50$ & 2681 & +2.1 \\
\hline P-2 WR & $\begin{array}{l}\text { Hornblendite } \\
\text { (dyke) }\end{array}$ & 7 & 1.718 & 8.94 & 0.1162 & $0.511510 \pm 10$ & 2452 & -0.6 \\
\hline P-2 Amf-1 & Amphibole & & 1.201 & 6.67 & 0.1088 & $0.511405 \pm 19$ & & \\
\hline P-2 Opx & Orthopyroxene & & 0.400 & 1.525 & 0.1586 & $0.512099 \pm 23$ & & \\
\hline P-2 Cpx & Clinopyroxene & & 0.545 & 2.09 & 0.1549 & $0.512026 \pm 15$ & & \\
\hline P-2 Amf-2 & Amphibole & & 0.841 & 4.69 & 0.1055 & $0.511335 \pm 35$ & & \\
\hline P-1/1 WR & Harzburgite & 3 & 0.014 & 0.119 & 0.0697 & $0.510636 \pm 11$ & 2650 & +1.3 \\
\hline $\mathrm{P}-1 / 1 \mathrm{Ol}$ & Olivine & & 0.012 & 0.114 & 0.0644 & $0.510535 \pm 18$ & & \\
\hline $\mathrm{P}-1 / 1 \mathrm{Cpx}$ & Clinopyroxene & & 0.036 & 0.159 & 0.1384 & $0.511777 \pm 7$ & & \\
\hline $\mathrm{P}-1 / 1 \mathrm{Opx}$ & Orthopyroxene & & 0.038 & 0.176 & 0.1297 & $0.511620 \pm 14$ & & \\
\hline P-1/1 Chr & Chromite & & 0.012 & 0.444 & 0.0162 & $0.509786 \pm 16$ & & \\
\hline A-1 WR * & Orthopyroxenite & 6 & 0.054 & 0.237 & 0.1306 & $0.511868 \pm 17$ & 2345 & +1.1 \\
\hline A-1 Chr-Spl * & Chrome-spinellid & & 0.017 & 0.083 & 0.1208 & $0.511775 \pm 27$ & & \\
\hline A-1 Opx-1 * & Orthopyroxene & & 0.097 & 0.435 & 0.1344 & $0.511926 \pm 30$ & & \\
\hline A-1 Opx-2* & Orthopyroxene & & 0.055 & 0.233 & 0.1419 & $0.512028 \pm 20$ & & \\
\hline
\end{tabular}

*: data from [47].

The $\mathrm{Sm}-\mathrm{Nd}$ age of harzburgites was estimated on monomineral concentrates $\mathrm{Ol}, \mathrm{Opx}, \mathrm{Cpx}, \mathrm{Chr}$, and rock (whole-rock) at $2475 \pm 38, \varepsilon_{\mathrm{Nd}}(\mathrm{T})=+1.5 \pm 0.5$ (Figure 7, Table 1). 


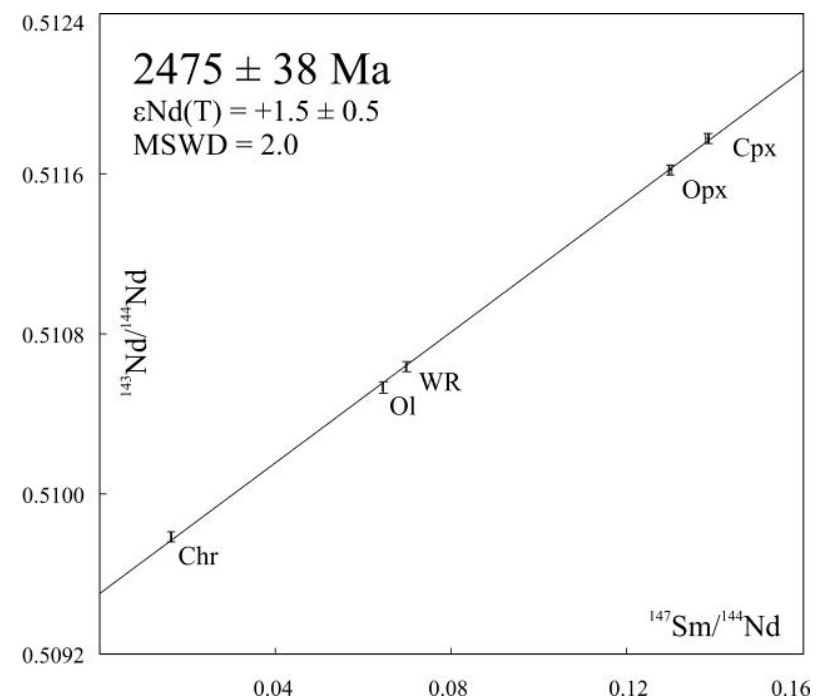

Figure 7. Mineral Sm-Nd isochron for harzburgites (P-1/1) with chromite mineralization, rhythmically layered series, third rhythm.

\subsection{Dating the Hornblende Dykes}

The U-Pb and Sm-Nd ages of hornblendite dykes were estimated at ca. $2080 \mathrm{Ma}$ (Figures 8 and 9, Tables 1 and 2). The U-Pb age on rutile from hornblendite dykes is $1804 \pm 10 \mathrm{Ma}$, which corresponds with the postobduction cooling of the rocks in the complex to $450-400{ }^{\circ} \mathrm{C}$.

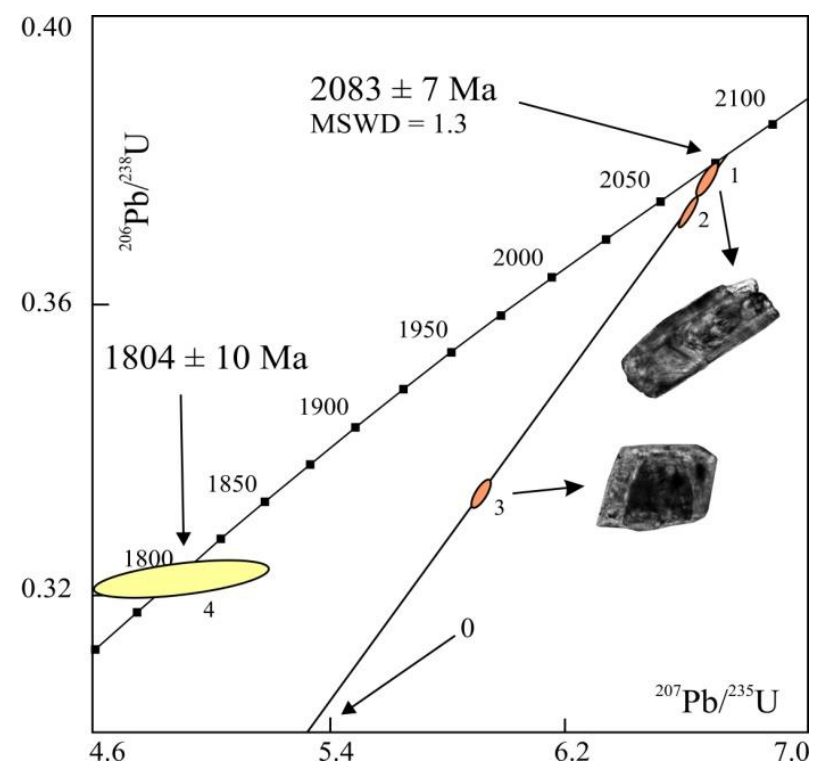

Figure 8. U-Pb plot with concordia on zircon (orange ellipses, 1-3) and rutile (yellow ellipse, 4) from a hornblendite dyke in the Pados-Tundra complex (sample P-3).

Table 2. Isotope U-Pb data on zircon (1-3) and rutile (4) from a hornblendite dyke (P-3).

\begin{tabular}{ccccccccccc}
\hline \multirow{2}{*}{ No } & $\begin{array}{c}\text { Weight, } \\
\mathbf{m g}\end{array}$ & \multicolumn{3}{l}{ Concentrationppm } & \multicolumn{3}{c}{ Pb Isotope Ratios } & \multicolumn{3}{c}{ Isotope Ratios and Age, $\mathbf{M a}$} \\
\hline
\end{tabular}




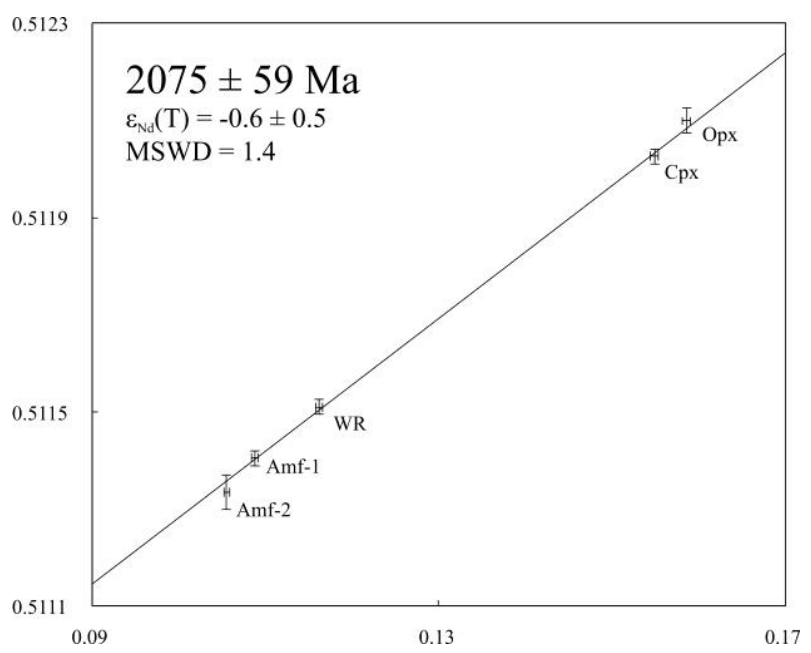

Figure 9. Sm-Nd mineral isochron for a hornblendite dyke (sample P-2).

\section{Discussion}

The Sm-Nd age of rocks in the rhythmically layered series of the complex is $2485 \pm 77 \mathrm{Ma}$ (whole-rock isochron) and $2475 \pm 38 \mathrm{Ma}$ (mineral isochron). It coincides with the age of layered intrusions in the Baltic Shield [11,12,15,36,87-94]. The model Sm-Nd age (TDM) of the analyzed samples is close to $2.7-2.8 \mathrm{Ga}$. It is not typical of rocks from layered intrusions in the Baltic Shield, whose model ages are commonly more ancient and equal 2.9-3.2 Ga [11-13]. The $\varepsilon \mathrm{Nd}(\mathrm{T})$ values for the studied samples range from +1.6 to +2.3 and are close to $\varepsilon N d(T)$ values of rocks from a drusite complex of the Belomorian mobile belt with the similar age [87], that is, +0.70 to +1.05 (Figure 10). These values (younger model ages and positive $\varepsilon N d$ values) can be linked to the evolution of the second plume in the past [40].

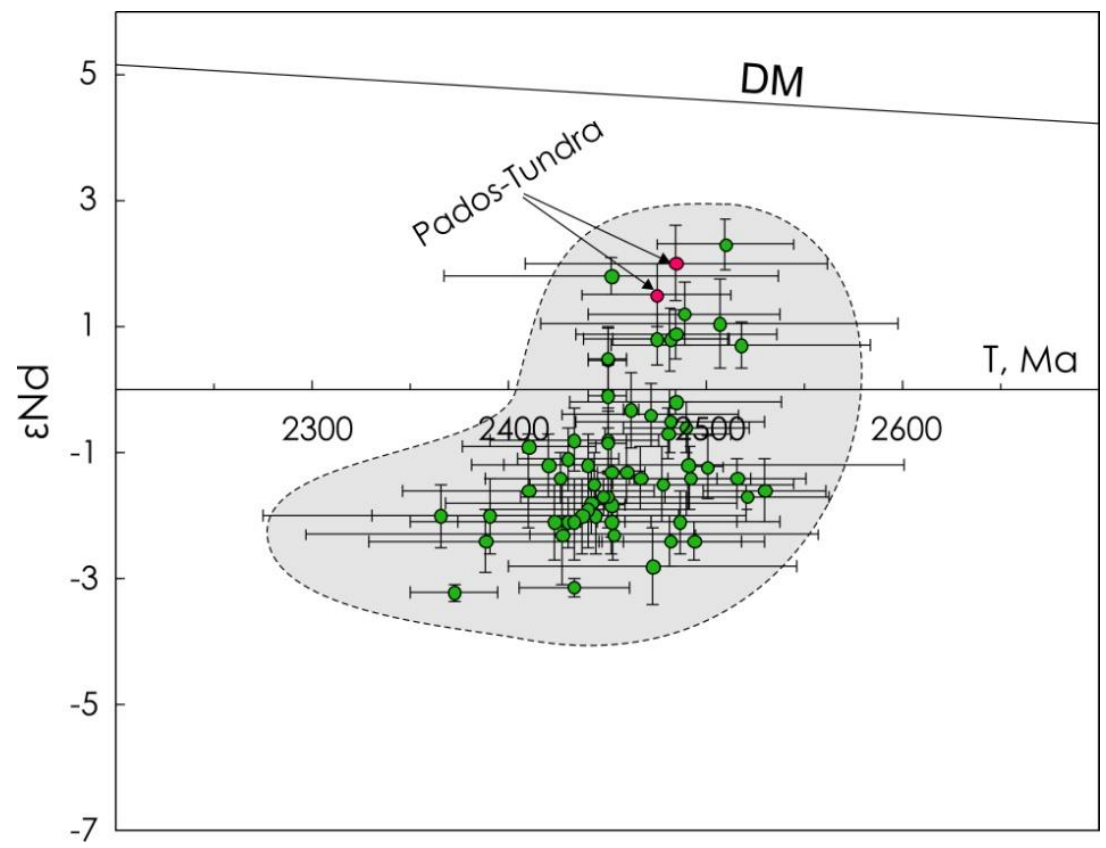

Figure 10. Plot for $\varepsilon \mathrm{Nd}(\mathrm{T})$ vs $\mathrm{T}$ for layered intrusions $(2.53-2.39 \mathrm{Ga})$ in the Fennoscandian Shield and Pados-Tundra complex. Isotope data from [3-5,11-13,15,16,19,21-26,28-33,35-39,41,87,89-94].

The intrusive magmatism at 2.53-2.39 Ga was widespread not only in the Fennoscandian Shield, but also in Canada [95-98] and Zimbabwe [99]. Thus, the conducted research allows the reconstruction 
of the main stages in evolution of the matter in the Pados-Tudra complex. The intrusion originated at the edge of 2485-2475 Ma, at the turn of the Archean and Paleoproterozoic. The clearly traced rhythmic layering of rocks in the complex suggests a fluid (initial phase) and crystallization differentiation (next stage) of the melt in the intrusive chamber. This event is temporally constrained by the age of rocks in the rhythmically layered series ( $2485 \pm 77 \mathrm{Ma}$ and $2475 \pm 38 \mathrm{Ma}$ ) defined by the Sm-Nd method.

Hornblendite dykes intruded when the rhythmically layered series of the intrusion and its chromite mineralization were finally formed. Complex $\mathrm{U}-\mathrm{Pb}$ and $\mathrm{Sm}-\mathrm{Nd}$ studies have estimated the age of these dykes at ca. $2080 \mathrm{Ma}$. Though these dykes occur unconformably to rocks in rhythmic series, the dykes intruded much later than the complex formed, before the Lapland granulites and acid magmatism occurred [43]. In general, the estimated age is close to the age of rocks in the Tanaelv and Kolvitsa Melange (2056-2041 Ma) [62,88]. It marks the origination of the Lapland-Kola Ocean [62] in the late Proterozoic. However, it is possible that isotope systems transformed at the level of minerals and rocks as a result of intense metasomatism during the regional metamorphism at the turn of 1.95-1.90 Ga. It could provide much younger ages of hornblendites. This issue should be clarified by supplementary studies. The successive regional metamorphism at the turn of 1.95-1.90 Ga [54,62], overthrusting of Lapland granulites, and the associated acid magmatism provided global changes in the structure of the complex. As a result, dyke bodies of granites and metasomatically altered rocks and epigenetic formations, as well as talc-magnesite, asbestos, and magnetite ores, were formed in the complex. These processes triggered transformations in $\mathrm{Sm}-\mathrm{Nd}$ isotope systems in minerals and rocks, restarted the "isotope clocks", and produced metamorphic mineral species. Based on isotope Sm-Nd data on metamorphic minerals, the age of postmetamorphic cooling of the complex rocks to $650-600^{\circ} \mathrm{C}$ has been estimated at $1872 \pm 76 \mathrm{Ma}$. The U-Pb age on rutile (1804 $\pm 10 \mathrm{Ma}$, Figure 8, Table 2$)$ from a hornblendite dyke indicates further cooling to $450-400{ }^{\circ} \mathrm{C}$ [88]. The close $\mathrm{Sm}-\mathrm{Nd}$ age on whole-rock and metamorphic rutile $(1872 \pm 76 \mathrm{Ma}[43,44])$ has been estimated for amphibolized metagabbronorites in the Maliy Pados. The estimated age is interpreted as a time constraint of the postmetamorphic cooling of rocks to the temperature of $650-600{ }^{\circ} \mathrm{C}$. It complies with the temperature of the isotope $\mathrm{Sm}-\mathrm{Nd}$ system closure in granites from 1.89-Ga-old aluminiferous gneisses in the Yavr-Pados-Nota area [88].

This stage is also marked with intense tectonic activity that produced fractures of the northeastern strike, granitic dykes, and ore occurrences of talc-magnesite, asbestos, and superposed magnetite and sulfide ores.

An almost total absence of clinopyroxene in the composition of the rocks can indicate that these ultramafites could form from the primitive mantle source of the komatiitic composition [100], like in the Chapesvara dunite-orthopyroxenite complex [101], which is also part of the Notozero ultramafic belt and similar with the Pados-Tundra complex in composition and settings of occurrence.

The obtained isotope-geochronological data combined with results of previous geochemical, petrological, and mineralogical studies of the complex [43-47,72-74] allow referring it to the vast Paleoproterozoic East Scandinavian LIP, which is associated with rich deposits of strategic mineral raw materials (i.e., Cr, Cu-Ni-Co and PGE) [1-6,12-19,21-27,29-39,41,42,54,87,89-92,94].

\section{Conclusions}

The newly obtained dates indicate an older age for the Pados-Tundra complex than the until not admitted age $2.15 \mathrm{Ga}$ age, which is also the age of the Paleoproterozoic mafic-ultramafic $\mathrm{Cu}-\mathrm{Ni}-\mathrm{Co}-\mathrm{Cr}-\mathrm{PGE}$ systems in the Fennoscandian Shield. According to results of our study, the Pados-Tundra evolution can be reconstructed in three stages:

(i) the emplacement of the layered Cr-bearing intrusion occurred at $2485 \pm 77 \mathrm{Ma}-2475 \pm 38 \mathrm{Ma}$;

(ii) horblendite dykes were intrusive at $2075 \pm 59 \mathrm{Ma}$, which can be related to the origination of the Lapland-Kola Ocean; 
(iii) the complex was reworked at a tectono-metamorphic event at ca. $1.9 \mathrm{Ga}$, apparently coeval with the regional overthrust of the LGB [54,62]; the final cooling at $450-400{ }^{\circ} \mathrm{C}$ is recorded by $\mathrm{U}-\mathrm{Pb}$ dating of rutile at $1804 \pm 10$ Ma.

Thus, the Pados-Tundra dunite-harzburgite-orthopyroxenite complex (and, probably, other ultramafic intrusions of the Notozero complex) belongs to the East Scandinavian LIP [12], in which metallogenic specialization $[11,12,36]$ suggests the presence of major deposits of Cu-Ni-PGE raw materials and $\mathrm{Cr}$. Thus, the western part of the Kola Peninsula is promising for chromite raw materials, which is economically valuable for development of the raw material base in the Russian Arctic.

Author Contributions: Conceptualization, T.B.B. and P.A.S.; methodology, P.A.S. and E.L.K.; software, P.A.S., T.B.B., and E.L.K; validation, P.A.S., T.B.B., E.L.K., E.N.S., and E.S.B.; formal analysis, P.A.S.; investigation, P.A.S., T.B.B., E.L.K., E.N.S., and E.S.B.; resources, E.L.K., E.N.S., and E.S.B.; data curation, P.A.S. and T.B.B.; writing-original draft preparation, P.A.S., T.B.B.; visualization, P.A.S. and E.N.S.; supervision, P.A.S. and T.B.B.; project administration, E.N.S. and T.B.B.; funding acquisition, T.B.B. All authors have read and agreed to the published version of the manuscript.

Funding: The research has been carried out in the framework of the Scientific Research Contract of GI KSC RAS No. 0226-2019-0053 and funded by the Russian Foundation for Basic Research (grants No. 18-05-70082, 18-35-00246, 18-35-00152).

Acknowledgments: The authors thank O.G. Sherstenikova and N.A. Ekimova (GI KSC RAS) for their help in chemical preparation of rocks; L.M. Lyalina (GI KSC RAS) for her assistance in studying the structure of the minerals; L.I. Koval (GI KSC RAS) for extraction of mineral fractions and grinding of rocks. We are also grateful to anonymous reviewers for their valuable remarks that helped to improve the paper.

Conflicts of Interest: The authors declare no conflict of interest.

\section{References}

1. Karykowski, B.T.; Maier, W.D.; Groshev, N.Y.; Barnes, S.-J.; Pripachkin, P.V.; McDonald, I.; Savard, D. Critical controls on the formation of contact-style PGE-Ni-Cu mineralization: Evidence from the Paleoproterozoic Monchegorsk Complex, Kola region, Russia. Econ. Geol. 2018, 113, 911-935. [CrossRef]

2. Maier, W.D.; Hanski, E.J. Layered mafic-ultramafic intrusions of Fennoscandia: Europe's treasure chest of magmatic metal deposits. Elements 2017, 13, 415-420. [CrossRef]

3. Nerovich, L.I.; Bayanova, T.B.; Serov, P.A.; Elizarov, D.V. Magmatic sources of dikes and veins in the Moncha Tundra Massif, Baltic Shield: Isotopic-geochronologic and geochemical evidence. Geochem. Int. 2014, 52, 548-566. [CrossRef]

4. Sharkov, E.V.; Chistyakov, A.V. Geological and petrological aspects of Ni-Cu-PGE mineralization in the Early Paleoproterozoic Monchegorsk layered mafic-ultramafic complex, Kola Peninsula. Geol. Ore Depos. 2014, 56, 147-168. [CrossRef]

5. Yang, S.H.; Hanski, E.; Li, C.; Maier, W.D.; Huhma, H.; Mokrushin, A.V.; Latypov, R.; Lahaye, Y.; O’Brien, H.; $\mathrm{Qu}$, W.-J. Mantle source of the 2.44-2.50-Ga mantle plume-related magmatism in the Fennoscandian Shield: Evidence from $\mathrm{Os}, \mathrm{Nd}$ and $\mathrm{Sr}$ isotope compositions of the Monchepluton and Kemi intrusions. Miner. Depos. 2016, 51, 1055-1073. [CrossRef]

6. Hanski, E.; Huhma, H.; Smolkin, V.F.; Vaasjoki, M. The age of the ferropicritic volcanics and comagmatic Ni-bearing intrusions at Pechenga, Kola Peninsula, USSR. Bull. Geol. Soc. Finl. 1990, 62, 123-133. [CrossRef]

7. Sharkov, E.V.; Smolkin, V.F. The Early Proterozoic Pechenga-Varzuga Belt: A case history of Precambrian back-arc spreading. Precambrian Res. 1997, 82, 133-151. [CrossRef]

8. Walker, R.J.; Morgan, J.W.; Hanski, E.J.; Smolkin, V.F. Re-Os systematics of early Proterozoic ferropicrites, Pechenga complex, NW Russia: Evidence for ancient ${ }^{187}$ Os-enriched plumes. Geochim. Cosmochim. Acta 1997, 61, 3145-3160. [CrossRef]

9. Neradovsky, Y.N.; Alekseeva, S.A.; Chernousenko, E.V. Mineralogy and process properties of Kolvitsky titanomagnetite ore. In IOP Conference Series: Earth and Environmental Science; IOP Publishing: Bristol, UK, 2019; Volume 262, p. 012050.

10. Voitekhovskii, Y.L.; Neradovskii, Y.N.; Grishin, N.N.; Rakitina, E.Y.; Kasikov, A.G. The Kolvitskoe deposit (geology, material composition of ores). Vestnik MGTU 2014, 17, 271-278. 
11. Baynova, T.; Ludden, J.; Mitrovanov, F. Timing and duration of Paleoproterozoic ore-bearing layered intrusions of the Baltic Shield: Metallogenic, petrological and geodynamic implications. In Paleoproterozoic Supercontinents and Global Evolution; Reddy, S.M., Mazumder, R., Evans, D.A., Collins, A.S., Eds.; Geological Society of London: London, UK, 2009; Volume 323, pp. 165-198.

12. Mitrofanov, F.P.; Bayanova, T.B.; Ludden, J.N.; Korchagin, A.U.; Chashchin, V.V.; Nerovich, L.I.; Serov, P.A.; Mitrofanov, A.F.; Zhirov, D.V. Origin and Exploration of the Kola PGE-bearing Province: New Constraints from Geochronology. In Ore Deposits: Origin, Exploration, and Exploitation; Geophysical Monograph Series; Sophie Decree, S., Robb, L., Eds.; Wiley: Hoboken, NJ, USA, 2019; pp. 3-36. [CrossRef]

13. Mitrofanov, F.; Golubev, A. Russian Fennoscandian metallogeny. In Abstracts of the 33 IGC; Norwegian Academy of Science and Letters: Oslo, Norway, 2008.

14. Schissel, D.; Tsvetkov, A.A.; Mitrofanov, F.P.; Korchagin, A.U. Basal Platinum-Group Element Mineralization in the Fedorov Pansky Layered Mafic Intrusion, Kola Peninsula, Russia. Econ. Geol. 2002, 97, 1657-1677. [CrossRef]

15. Amelin, Y.V.; Heaman, L.M.; Semenov, V.S. U-Pb geochronology of layered mafic intrusions in the eastern Baltic Shield: Implications for the timing and duration of Paleoproterozoic continental rifting. Precambrian Res. 1995, 75, 31-46. [CrossRef]

16. Huhma, H.; Clift, R.A.; Perttunen, V.; Sakko, M. Sm-Nd and Pb isotopic study of mafic rocks associated with early Proterozoic continental rifting: The Perapohja schist belt in northern Finland. Contrib. Mineral. Petrol. 1990, 104, 369-379. [CrossRef]

17. Halkoaho, T.; Alapieti, T.T.; Lahtinen, J.J. The Sompujarvi PGE mineralization in the Penikat layered intrusion. In Proceedings of the 5th International Platinum Symposium: Guide to the Post-Symposium Field Trip, Helsinki, Finland, 4-11 August 1989; Volume 29, pp. 71-92.

18. Halkoaho, T.A.A.; Alapieti, T.T.; Lahtinen, J.J. The Sompujarvi PGE Reef in the Penikat layered intrusion, Northern Finland. Miner. Petrol 1990, 42, 39-55. [CrossRef]

19. Hanski, E.; Walker, R.J.; Huhma, H.; Suominen, I. The Os and Nd isotopic systematics of c. 2.44 Ga Akanvaara and Koitelainen mafic layered intrusions in northern Finland. Precambrian Res. 2001, 109, 73-102. [CrossRef]

20. Iljina, M.; Maier, W.D.; Karinen, T. PGE-(Cu-Ni) deposits of the Tornio-Näränkävaara belt of intrusions (Portimo, Penikat and Koillismaa). In Mineral Deposits of Finland; Maier, W.D., Lahtinen, R., O’Brien, H., Eds.; Elsevier: Amsterdam, The Netherlands, 2015; pp. 133-164.

21. Balashov, Y.A.; Bayanova, T.B.; Mitrofanov, F.P. Isotope data on the age and genesis of layered basic-ultrabasic intrusions in the Kola Peninsula and northern Karelia, northeastern Baltic Shield. Precambrian Res. 1993, 64, 197-205. [CrossRef]

22. Bayanova, T.B. Age of Reference Geological Complexes of the Kola Region and the Duration of Igneous Processes; Nauka: Saint Petersburg, Russia, 2004; p. 174. (In Russian)

23. Bayanova, T.B. Baddeleyite: A promising geochronometer for alkaline and basic magmatism. Petrology 2006, 14, 187-200. [CrossRef]

24. Huber, M.; Halas, S.; Serov, P.A.; Ekimova, N.A.; Bayanova, T.B.Sm-Nd dating and stable isotope geochemistry of sulfides and $\mathrm{U}-\mathrm{Pb}$ ages of layered intrusions from the northern part of the Baltic Shield. Mineralogia 2012, 39, 107-108.

25. Huhma, H.; Mutanen, N.; Hanski, E. Sm-Nd isotopic evidence for contrasting sources of the prolonged Paleoproterozoic mafic-ultramafic magmatism in Central Finnish Lapland. In Proceedings of the IGCP Project 336 Symposium, Rovaniemi, Finland, 21-23 August 1996; Volume 33, pp. 57-58.

26. Mitrofanov, F.P.; Balagansky, V.V.; Balashov, Y.A.; Gannibal, L.F.; Dokuchaeva, V.S.; Nerovich, L.I.; Radchenko, M.K.; Ryungenen, G.I. U-Pb age for gabbro-anorthosite of the Kola Peninsula. Dokl. Earth Sci 1993, 331, 95-98.

27. Peltonen, P.; Brugmann, G. Origin of layered continental mantle (Karelian craton, Finland): Geochemical and Re-Os isotope constraints. Lithos 2006, 89, 405-423. [CrossRef]

28. Puchtel, I.S.; Brugmann, G.E.; Hofmann, A.W.; Kulikov, V.S.; Kulikova, V.V. Os isotope systematics of komatiitic basalts from the Vetreny belt, Baltic Shield: Evidence for a chondritic source of the 2.45 Ga plume. Contrib. Mineral. Petrol. 2001, 140, 588-599. [CrossRef]

29. Serov, P. Comparison between Sm-Nd Rock-Forming Mineral and U-Pb Zircon and Baddeleyite Data of the Fedorovo-Pansky Pt-bearing Layered Intrusion; European Geosciences Union: Vienna, Austria, 2007; EGU2007-A-01156. 
30. Serov, P. New Sm-Nd isotope-geochemical data for the Fedorovo-Pansky PGE-bearing layered intrusion (N-E Fennoscandian Shield). In Geophysical Research Abstracts; European Geosciences Union: Vienna, Austria, 2012; EGU2010-8143.

31. Serov, P.; Bayanova, T. Palaeoproterozoic Fedorovo-Pansky PGE-bearing layered intrusion of the N-E Baltic Shield: New isotope data. In 33 IGC; Norwegian Academy of Science and Letters: Oslo, Norway, 2008.

32. Serov, P.; Ekimova, N.; Bayanova, T. Isotope-geochemical Nd-Sr evidence of Palaeoproterozoic plume magmatism in Fennoscandia and mantle-crust interaction on stages of layered intrusions formation. In Geophysical Research Abstracts; European Geosciences Union: Vienna, Austria, 2012; Volume 14, EGU2012-9113.

33. Serov, P.A.; Ekimova, N.A.; Bayanova, T.B.; Mitrofanov, F.P. Sulfide minerals as new geochronometers during $\mathrm{Sm}-\mathrm{Nd}$ dating of the ore genesis for layered mafic and ultramafic intrusions. Lithosphere 2014, 4, 11-21.

34. Sharkov, E.V. Petrology of Layered Intrusions; Nauka: Saint Petersburg, Russia, 1980; p. 183. (In Russian)

35. Vogel, D.C.; Vuollo, J.I.; Alapieti, T.T.; James, R.S. Tectonic, stratigraphic and geochemical comparison between ca. 2500-2440 Ma mafic igneous events in the Canadian and Fennoscandian Shields. Precambrian Res. 1998, 92, 89-116. [CrossRef]

36. Bayanova, T.; Korchagin, A.; Mitrofanov, A.; Serov, P.; Ekimova, N.; Nitkina, E.; Kamensky, I.; Elizarov, D.; Huber, M. Long-lived mantle plume and polyphase evolution of Palaeoproterozoic PGE intrusions in the Fennoscandian Shield. Minerals 2019, 9, 59. [CrossRef]

37. Bayanova, T.; Mitrofanov, F.; Serov, P.; Nerovich, L.; Yekimova, N.; Nitkina, E.; Kamensky, I. Layered PGE Paleoproterozoic (LIP) Intrusions in the N-E Part of the Fennoscandian Shield-Isotope Nd-Sr and ${ }^{3} \mathrm{He} /{ }^{4} \mathrm{He}$ Data, Summarizing U-Pb Ages (on Baddeleyite and Zircon), Sm-Nd Data (on Rock-Forming and Sulphide Minerals), Duration and Mineralization. In Geochronology_Methods and Case Studies; Morner, N.-A., Ed.; INTECH: London, UK, 2014; pp. 143-193.

38. Bayanova, T.B.; Rundkvist, T.V.; Serov, P.A.; Korchagin, A.U.; Karpov, S.M. The Palaeoproterozoic Fedorovo-Pansky layered PGE Complex of the northeastern Baltic Shield, Arctic Region: New U-Pb (Baddeleyite) and Sm-Nd (Sulfide) data. Dokl. Earth Sci. 2017, 472, 1-5. [CrossRef]

39. Chashchin, V.V.; Bayanova, T.B.; Mitrofanov, F.P.; Serov, P.A. Low-sulfide PGE ores in Palaeoproterozoic Monchegorsk Pluton and massifs of its southern framing, Kola Peninsula, Russia: Geological characteristic and isotope geochronological evidence of polychronous ore-magmatic systems. Geol. Ore Depos. 2016, 58, 37-57. [CrossRef]

40. Ernst, R.E. Large Igneous Provinces; Cambridge University Press: Cambridge, UK, 2014; 653p.

41. Alapieti, T.; Filen, B.; Lahtinen, J.; Lavrov, M.; Smolkin, V.; Voitsekhovsky, S. Early Proterozoic layered intrusions in the northeastern part of the Fennoscandian Shield. Miner. Petrol. 1990, 42, 1-22. [CrossRef]

42. Melezhik, V.A.; Hanski, E.J. The Pechenga Greenstone Belt. In Reading the Archive of Earth's Oxygenation, Volume 1: The Palaeoproterozoic of Fennoscandia as Context for the Fennoscandian Arctic Russia-Drilling Early Earth Project, Frontiers in Earth Sciences; Melezhik, V.A., Prave, A.R., Fallick, A.E., Kump, L.R., Strauss, H., Lepland, A., Hanski, E.J., Eds.; Springer: Berlin/Heidelberg, Germany, 2012; pp. 289-385.

43. Mamontov, V.P.; Dokuchaeva, V.S. The geology and ore potential of the Pados-Tundra massif in the Kola Peninsula. Otechestvennaya Geol. 2005, 6, 52-60. (In Russian)

44. Vinogradov, L.A. The formation of ultrabasic rocks in the south-western part of the Kola Peninsula (The Notozersky ultrabasic belt). In Problems of Magmatism of the Baltic Shield; Nauka: Saint Petersburg, Russia, 1971; pp. 147-153. (In Russian)

45. Zak, S.I. The Lower Proterozoic Ultrabasic Formations of the Kola Peninsula; Nauka: Saint Petersburg, Russia, 1980; 160p. (In Russian)

46. Shapkin, S.; Bayanova, T. Geochronological Sm-Nd dating of the Cr-PGE-bearing Pados Massif (North-West Baltic Shield): New mineral and rock isochrons. In Geophysical Research Abstracts; European Geosciences Union: Vienna, Austria, 2009; EGU2009-339-3.

47. Shapkin, S.S.; Bayanova, T.B.; Serov, P.A. Pados-Tundra New Sm-Nd and U-Pb data for rocks of the massif (western part of the Kola Peninsula). In Proceedings of the XIX Conference of Young Scientists in the Memory of Professor K.O. Kratz, 24-28 November 2008; Geological Institute, Kola Science Centre: Apatity, Russia, 2008; pp. 63-66. (In Russian) 
48. Lahtinen, R.; Korja, A.; Nironen, M. Palaeoproterozoic tectonic evolution of the Fennoscandian Shield. In The Precambrian Bedrock of Finland-Key to the Evolution of the Fennoscandian Shield; Lehtinen, M., Nurmi, P., Ramo, T., Eds.; Elsevier Science B.V.: Amsterdam, The Netherlands, 2005; pp. 418-532.

49. Williams, H.; Hoffman, P.H.; Lewry, J.F.; Monger, J.W.H.; Rivers, T. Anatomy of North America: Thematic geologic portrayals of the continents. Tectonophysics 1991, 187, 117-134. [CrossRef]

50. Aspler, L.B.; Chiarenzelli, J.R. Two Neoarchean supercontinents? Evidence from the Paleoproterozoic. Sediment. Geol. 1998, 120, 75-104. [CrossRef]

51. Lubnina, N.; Slabunov, A. Reconstruction of the Kenorland supercontinent in the Neoarchean based on paleomagnetic and geological data. Mosc. Univ. Geol. Bull. 2011, 66, 242-249. [CrossRef]

52. Bleeker, W. The late Archean record: A puzzle in ca. 35 pieces. Lithos 2003, 71, 99-134. [CrossRef]

53. Meert, J.G. What's in a name? The Columbia (Paleopangaea/Nuna) supercontinent. Gondwana Res. 2012, 21, 987-993. [CrossRef]

54. Hanski, E. Evolution of the Palaeoproterozoic (2.50-1.95 Ga) non-orogenic magmatism in the eastern part of the fennoscandian shield. In Reading the Archive of Earth's Oxygenation, Volume 1: The Palaeoproterozoic of Fennoscandia as Context for the Fennoscandian Arctic Russia-Drilling Early Earth Project, Frontiers in Earth Sciences; Melezhik, V.A., Prave, A.R., Fallick, A.E., Kump, L.R., Strauss, H., Lepland, A., Hanski, E.J., Eds.; Springer: Berlin/Heidelberg, Germany, 2012; pp. 179-245.

55. Barbey, P.; Convert, J.; Morean, B.; Capdevila, R.; Hameurt, J. Petrogenesis and evolution of an erly Proterozoic collisional orogenic belt: The granulite belt of Lapland and the Belomorides (Fennoscandia). Bull. Geol. Soc. Finl. 1984, 56, 161-188. [CrossRef]

56. Krill, A.G. Svecokarelian thrusting with thermal inversion in the Karasjok-Levajok area of the northern Baltic Shield. Nor Geol Unders 1985, 403, 89-101.

57. Priyatkina, L.A.; Sharkov, E.V. Geology of the Lapland Deep-Seated Fault; Nauka Press: Saint Petersburg, Russia, 1979; 210p. (In Russian)

58. Marker, M. Early Proterozoic thrusting of the Lapland granulite belt and its geotectonic evolution, northern Baltic Shield. Geol. Foren Stockh. Forh. 1988, 110, 405-410. [CrossRef]

59. Barbey, P.; Raith, M. The granulite belt of Lapland. In Granulites and Crustal Evolution; Vielzeuf, D., Vidal, P., Eds.; Kluwer: Dordrecht, The Netherlands, 1990; pp. 111-132.

60. Lobach-Zhuchenko, S.B.; Bibikova, E.V.; Drugova, G.M.; Beliackiy, E.V.; Gracheva, T.V.; Amelin, Y.V.; Matrenichev, V.A. Geochronology and petrology of magmatic complex of the Tupaya Guba, N-W Belomorie, Kola Peninsula. Petrology 1993, 1, 657-677.

61. Bernard-Griffits, J.; Peucat, J.J.; Postaire, B.; Vidal, P.; Convert, J.; Moreau, B. Isotopic data (U-Pb, Rb-Sr, $\mathrm{Pb}-\mathrm{Pb}$ and $\mathrm{Sm}-\mathrm{Nd}$ ) on mafic granulites from Finnish Lapland. Precambrian Res. 1994, 23, 225-348. [CrossRef]

62. Daly, J.S.; Balagansky, V.V.; Timmerman, M.J.; Whitehouse, M.J. The Lapland-Kola orogen: Palaeoproterozoic collision and accretion of the northern Fennoscandian lithosphere. Geol. Soc. Lond. Mem. 2006, 32, 579-598. [CrossRef]

63. Perchuk, L.L.; Gerya, T.V.; Van Reenen, D.D.; Smit, C.A.; Krotov, A.V. P-T paths and tectonic evolution of shear zones separating high-grade terrains from cratons: Examples from Kola Peninsula (Russia) and Limpopo Region (South Africa). Mineral. Petrol. 2000, 69, 109-142. [CrossRef]

64. Mints, M.V.; Glaznev, V.N.; Konilov, A.N. The Early Precambrian of the North-Eastern Baltic Shield: Paleogeodynamics, Crustal Structure, and Evolution; Science World Press: Moscow, Russia, 1996; 312p, (In Russian, with extended English Abstract).

65. Volodichev, O.I. Belomorian Complex of Karelia (Geology and Petrology); Nauka Press: Saint Petersburg, Russia, 1990; p. 215. (In Russian)

66. Przhjialgovskiy, E.; Terekhov, E. Karasjok-Belomorian parautochton (2.2-1.9 Ga) and some aspects of structural and geochemical reworkig of rock complexes. Nor. Geol. Unders. Spec. Publ. 1995, 7, 193-200.

67. Garuti, G.; Proenza, J.A.; Zaccarini, F. Distribution and mineralogyof platinum-group elements in alteredchromitites of the Campo Formoso layeredintrusion (Bahia State, Brazil): Controlby magmatic and hydrothermal processes. Mineral. Petrol. 2007, 89, 159-188. [CrossRef]

68. Iljina, M.; Hanski, E. Layered mafic intrusions of the Tornio-Näränkävaara belt. In Precambrian Geology of Finland-Key to the Evolution of the Fennoscandian Shield. Developments in Precambrian Geology; Lehtinen, M., Nurmi, P.A., Rämö, O.T., Eds.; Elsevier Science B.V.: Amsterdam, The Netherlands, 2005; Volume 14, pp. 101-138. 
69. Alapieti, T.T.; Kujanpää, J.; Lahtinen, J.J.; Papunen, H. The Kemi stratiform chromitite deposit, northern Finland. Econ. Geol. 1989, 84, 1057-1077. [CrossRef]

70. Dokuchaeva, V.S. The geology and ore potential of the Mount Lyavaraka massif. In Geology of Ore Deposits in the Kola Peninsula; Kola Science Centre: Apatity, Russia, 1981; pp. 34-45. (In Russian)

71. Nikolaev, V.I. Chromite-bearing geological formations with large deposits and high-quality ores. Otechestvennaya Geol. 1998, 4, 58-63. (In Russian)

72. Barkov, A.Y.; Nikiforov, A.A.; Martin, R.F. The structure and cryptic layering of the Pados-Tundra ultramafic complex, Serpentinite belt, Kola Peninsula, Russia. Bull. Geol. Soc. Finl. 2017, 89, 35-56. [CrossRef]

73. Barkov, A.Y.; Nikiforov, A.A.; Tolstykh, N.D.; Shvedov, G.I.; Korolyuk, V.N. Compounds of Ru-Se-S, alloys of Os-Ir, framboidal Ru nanophases and laurite-clinochlore intergrowths in the Pados-Tundra complex, Kola Peninsula, Russia. Eur. J. Mineral. 2017, 29, 613-621. [CrossRef]

74. Barkov, A.Y.; Nikiforov, A.A.; Halkoaho, T.A.A.; Konnunaho, J.P. The origin of spheroidal patterns of weathering in the Pados-Tundra mafic-ultramafic complex, Kola Peninsula, Russia. Bull. Geol. Soc. Finl. 2016, 88, 105-113. [CrossRef]

75. Raczek, I.; Jochum, K.P.; Hofmann, A.W. Neodymium and strontium isotope data for USGS reference materials BCR-1, BCR-2, BHVO-1, BHVO-2, AGV-1, AGV-2, GSP-1, GSP-2 and eight MPI-DING reference glasses. Geostand. Geoanalytical Res. 2003, 27, 173-179. [CrossRef]

76. Tanaka, T.; Togashi, S.; Kamioka, H.; Amakawa, H.; Kagami, H.; Hamamoto, T.; Yuhara, M.; Orihashi, Y.; Yoneda, S.; Shimizu, H.; et al. JNdi-1: A neodymium isotopic reference in consistency with LaJolla neodymium. Chem. Geol. 2000, 168, 279-281. [CrossRef]

77. Ludwig, K.R. ISOPLOT/Ex-A Geochronological Toolkit for Microsoft Excel, Version 3.6; Berkeley Geochronology Center Special Publication: Berkeley, CA, USA, 2008; Volume 4, p. 76.

78. Bouvier, A.; Vervoort, J.D.; Patchett, P.J. The Lu-Hf and Sm-Nd isotopic composition of CHUR: Constraints from unequilibrated chondrites and implications for the bulk composition of terrestrial planets. Earth Planet. Sci. Lett. 2008, 273, 48-57. [CrossRef]

79. Goldstein, S.J.; Jacobsen, S.B. Nd and Sr isotopic systematics of river water suspended material implications for crystal evolution. Earth Planet. Sci. Lett. 1988, 87, 249-265. [CrossRef]

80. Krogh, T.E. A low-contamination method for hydrothermal dissolution of zircon and extraction of $\mathrm{U}$ and $\mathrm{Pb}$ for isotopic age determinations. Geochim. Cosmochimica Acta 1973, 37, 485-494. [CrossRef]

81. Schärer, U.; Gower, C.F. Crustal evolution in Eastern Labrador: Constraints from precise U-Pb ages. Precambrian Res. 1988, 38, 405-421. [CrossRef]

82. Schärer, U.; Wilmart, E.; Duchesne, J.-C. The short duration and anorogenic character of anorthosite magmatism: U-Pb dating of the Rogaland Complex, Norway. Earth Planet. Sci. Lett. 1996, 139, 335-350. [CrossRef]

83. Ludwig, K.R. PBDAT: A computer program for processing Pb-U-Th isotope data, version 1.22; Open-File Report 88-542; United States Geological Survey: Reston, VA, USA, 1991; 33p.

84. Ludwig, K.R. ISOPLOT/Ex: A Geochronological Toolkit for Microsoft Excel, Version 2.05; Berkeley Geochronology Center Special Publication: Berkeley, CA, USA, 1999; Volume 1, p. 49.

85. Steiger, R.; Jäger, E. Subcommission on geochronology: Convention on the use of decay constants in geoand cosmochronology. Earth Planet. Sci. Lett. 1977, 36, 359-362. [CrossRef]

86. Stacey, J.S.; Kramers, J.D. Approximation of terrestrial lead isotope evolution by a two-stage model. Earth Planet. Sci. Lett. 1975, 26, 207-221. [CrossRef]

87. Krivolutskaya, N.A.; Svirskaya, N.M.; Belyatsky, B.V.; Smolkin, V.F.; Mamontov, V.P.; Fanygin, A.S. Geochemical Specifics of Massifs of the Drusite Complex in the Central Belomorian Mobile Belt: II. Sm-Nd Isotopic System of the Rocks and the U-Pb Isotopic System of Zircons. Geochem. Int. 2010, 48, 1064-1083. [CrossRef]

88. Kaulina, T.V.; Belyaev, O.A.; Apanasevich, E.A.; Delenitsin, A.A.; Zhavkov, V.A.; Kozlova, N.E.; Serov, P.A. The evolution of metamorphism processes in the Lapland granulite belt (LHP) and Tan's belt: U-Pb and Sm-Nd data. In New Data on Geology and Mineral Resources of the Kola Peninsula; Mitrofanov, F.P., Ed.; Kola Science Centre: Apatity, Russia, 2005; pp. 34-53.

89. Serov, P.A. Frontiers of Age Forming PGE Mineralization Fedorovo-Pansky Layered Intrusions in Sm-Nd and $\mathrm{Rb}-\mathrm{Sr}$ Isotopic Characteristics. Ph.D. Thesis, Voronezh State University, Voronezh, Russia, 2008. 
90. Huhma, H.; Hanski, E.; Kontinen, A.; Vuollo, J.; Mänttäri, I.; Lahaye, Y. Sm-Nd and U-Pb isotope geochemistry of the Palaeoproterozoic mafic magmatism in eastern and northern Finland. Geol. Surv. Finl. Bull. 2018, 405, 150.

91. Maier, W.D. Geology and petrogenesis of magmatic Ni-Cu-PGE-Cr-V deposits: An introduction and overview. In Mineral Deposits of Finland; Maier, W.D., Lahtinen, R., O’Brien, H., Eds.; Elsevier: Amsterdam, The Netherlands, 2015; p. 792.

92. Maier, W.D.; Groves, D.I. Temporal and spatial controls on the formation of magmatic PGE and Ni-Cu deposits. Miner. Depos. 2011, 46, 841-857. [CrossRef]

93. Puchtel, I.S.; Haase, K.M.; Hofmann, A.W.; Chauvel, C.; Kulikov, V.S.; Garbe-Schönberg, C.D.; Nemchin, A.A. Petrology and geochemistry of crustally contaminated komatiitic basalts from the Vetreny Belt, southeastern Baltic Shield: Evidence for an early Proterozoic mantle plume beneath rifted Archean continental lithosphere. Geochim. Cosmochim. Acta 1997, 61, 1205-1222. [CrossRef]

94. Barnes, S.-J.; Melezhik, V.A.; Sokolov, S.V. The composition and mode of formation of the Pechenga nickel deposits, Kola Peninsula, northwestern Russia. Can. Mineral. 2001, 39, 447-471. [CrossRef]

95. Ciborowski, T.J.R.; Kerr, A.C.; Ernst, R.E.; McDonald, I.; Minifie, M.J.; Harlan, S.S.; Millar, I.L. The early proterozoic Matachewan large Igneous Province: Geochemistry, petrogenesis, and implications for earth evolution. J. Petrol. 2015, 56, 1459-1494. [CrossRef]

96. Heaman, L.M. 2.5-2.4 Ga global magmatism:Remnants or supercontinents or products of superplumes. Geol. Soc. Am. 2004, 36, 255.

97. James, R.S.; Easton, R.M.; Peck, D.C.; Hrominchuk, J.L. The East Bull Lake intrusive suite: Remnants of a $2.48 \mathrm{Ga}$ large igneous and metallogenic province in the Sudbury area of the Canadian Shield. Econ. Geol. 2002, 97, 1577-1606. [CrossRef]

98. Iljina, M.J.; Lee, C.A. PGEdeposits in the marginal series of layered intrusions. In Exploration for Platinum-Group Elements Deposits; Mineralogical Association of Canada: Québec, QC, Canada, 2005; pp. 75-96.

99. Söderlund, U.; Hofmann, A.; Klausen, M.B.; Olsson, J.R.; Ernst, R.E.; Persson, P.-O. Towards a complete magmatic barcode for the Zimbabwe craton: Baddeleyite $\mathrm{U}-\mathrm{Pb}$ dating of regional dolerite dyke swarms and sill complexes. Precambrian Res. 2010, 183, 388-398. [CrossRef]

100. Arndt, N.T. Differentiation of Komatiite Flows. J. Petrol. 1986, 27, 279-301. [CrossRef]

101. Barkov, A.Y.; Korolyuk, V.N.; Barkova, L.P.; Martin, R.F. Double-Front Crystallization in the Chapesvara Ultramafic Subvolcanic Complex, Serpentinite Belt, Kola Peninsula, Russia. Minerals 2020, 10, 14. [CrossRef] 